
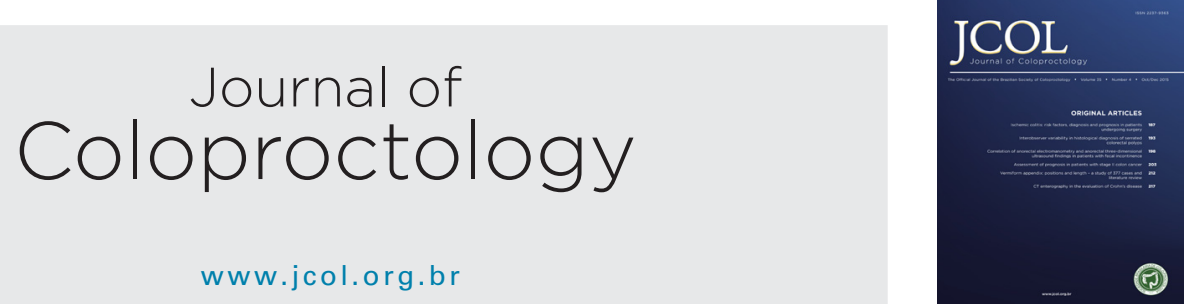

Original Article

\title{
Use of local anesthetic for the resolution of benign anorectal pathology in the Social Security Institute of Guatemala (IGSS)
}

\author{
Pablo Maldonado Hernández (i)*, Laura Ramírez Godoy, Maxi Méndez Morán, \\ Jorge San José Gómez, Juan Pablo Cordoba Paíz
}

Instituto Guatemalteco de Seguridad Social, Guatemala

\section{A R T I C L E I N F O}

\section{Article history:}

Received 10 September 2019

Accepted 6 October 2019

Available online 7 November 2019

Keywords:

Analgesia

Local block

Anorectal pathology

Guatemala

Social Security

\begin{abstract}
A B S T R A C T
Introduction: The use of regional anesthetic block has increased, along with the reduction of the use of spine anesthetic in this particular field of surgical activity. In the last decade ambulatory surgery and local anesthetic have lower surgical time, complications of the anesthetic itself, and hospital stay.

Objective: Presenting the results obteained with the use of local anesthesic and analgesic in the resolution of benign anorectal pathology.

Methods: A prospective, longitudinal, study, from January 2017 to December 2017, patients were classified according to surgical procedures performed using analogical visual scale to determine the pain tolerance, during the procedure, $24 \mathrm{~h}$ later and in the 5 th post operative day.

Results: 253 procedures were performed with 116 local analgesia, 116 were male (45.86\%) years 137 female (54\%), Milligan-Morgan hemorroidectomy with Ligasure and fistulotomy were the most frequently performed procedures $32 \%$ each, followed by biopsy $16 \%$, left lateral esfinterotomy $13 \%$ and cutaneous appendix $12 \%$. Females presented better pain tolerance than males patients (92 vs. 81), 68\% referred good tolerance through the procedure. Conclusions: $68 \%$ of all the patients obtained good pain tolerance through anal anesthetic block, females manifested better pain tolerance than males, in non-complicated anorectal pathology local block ha shown to be safe and reproductible for the treatment of benign anorectal pathology in the Guatemalan Institute for Social Security.

(c) 2020 Sociedade Brasileira de Coloproctologia. Published by Elsevier Editora Ltda. This is an open access article under the CC BY-NC-ND license (http://creativecommons.org/
\end{abstract} licenses/by-nc-nd/4.0/).

\footnotetext{
* Corresponding author.

E-mail: phdpashpa@hotmail.com (P. Maldonado Hernández).

https://doi.org/10.1016/j.jcol.2019.10.009

2237-9363/@ 2020 Sociedade Brasileira de Coloproctologia. Published by Elsevier Editora Ltda. This is an open access article under the CC BY-NC-ND license (http://creativecommons.org/licenses/by-nc-nd/4.0/).
} 


\section{Uso de anestésico local para resolução de patologia anorretal benigna no Instituto Guatemalteco de Seguridade Social}

\section{R E S U M O}

Palauras-chave:

Analgesia

Bloqueio local

Patologia anorretal

Guatemala

Seguro Social
Introdução: O uso de bloqueio anestésico regional aumentou ao mesmo tempo em que diminuiu o uso do anestésico espinhal nesse campo específico da atividade cirúrgica. Na última década, a cirurgia ambulatorial e o anestésico local apresentaram um tempo cirúrgico menor, menos complicações associadas ao próprio anestésico e redução da permanência hospitalar.

Objetivo: Apresentar os resultados obtidos com o uso de anestésico local e analgésico na resolução da patologia anorretal benigna.

Métodos: Estudo prospectivo, longitudinal, realizado no período de janeiro a dezembro de 2017. Com o uso de uma escala visual analógica, os pacientes foram classificados para determinar a tolerância à dor durante o procedimento, 24 horas após a cirurgia e no quinto dia de pós-operatório.

Resultados: No total, 253 procedimentos foram realizados com 116 analgesias locais; 116 pacientes eram do sexo masculino (4586\%) e 137 do sexo feminino (54\%). A técnica de Milligan-Morgan para hemorroidectomia com ligadura e a fistulotomia foram os procedimentos realizados com mais frequência ( $32 \%$ cada), seguidos de biópsia (16\%), esfincterotomia lateral esquerda (13\%) e apêndice cutâneo (12\%). As mulheres apresentaram melhor tolerância à dor que os homens (92 vs. 81), e 68\% apresentaram boa tolerância durante o procedimento.

Conclusões: De todos os pacientes, $68 \%$ apresentaram boa tolerância à dor com o uso de bloqueio anestésico por via retal; as mulheres manifestaram melhor tolerância à dor que os homens. Na patologia anorretal não complicada, o bloqueio local mostrou ser seguro e reprodutível para o tratamento da patologia anorretal benigna no Instituto Guatemalteco de Seguridade Social.

(C) 2020 Sociedade Brasileira de Coloproctologia. Publicado por Elsevier Editora Ltda. Este é um artigo Open Access sob uma licença CC BY-NC-ND (http://creativecommons.org/ licenses/by-nc-nd/4.0/).

\section{Introduction}

Benign anorectal pathologies are one of the main consultations in the emergency services, some can be treated medically, bust most need surgical intervention depending on time of evolutions, size, location and answer to medical treatment. ${ }^{1-3}$

In the last decade ambulatory surgery and local anesthetic have diminished surgical time, complications of anesthetic itself, hospital stay and stress generated by going under general anesthetic, Martin and cols, on their publication, concluded: "in 18 years of experience, $70 \%$ of the anal canal surgery can basically made in ambulatory patients using local anesthetic or posterior perineal block with a low range or complications of $0.5 \%$.

Spinal anesthetic for minor rectal surgeries was the most used option for surgeons up until a few decades ago. However, disadvantages such as post-spinal headache, postoperative urinary retention, and the less likely risk of nervous injury. Regional anesthetic block has been an alternative. This local anesthetic technique was used by a few surgeons in the past. In our practice regional anesthetic block is exclusively reserved for low complexity procedures for benign pathology. ${ }^{4-6}$

The present's results were obtained in the use of local anesthetic block for benign anal pathology in the Guatemalan
Institute for Social Security, in the patients seen in the Colon and Rectum unit in 2007 (see Tables 1 and 2).

\section{Justification}

In the last decades with the use of local anesthetics multiple low-complexity procedures have been made, which reflects an improve in the patientś evolution and hospital costs by reducing the hospital stay in the Social Security Institute of Guatemala, this type of regional anesthetic have been used however there wasnt any institutional study that proves the safety and efficacy of the use of local anesthetic for benign anal pathology.

\section{Objective}

Present the results obtained through one year, with the use of local anesthetic in the surgical treatment of anorectal pathology.

\section{Methods and materials}

253 patients were documented with benign anorectal pathology uncomplicated, operated in the coloproctology unit of the Social Security Institute of Guatemala. In the period between January to December 2017, that fill the inclusion criteria. 
Table 1 - Performed procedures distribution.

\begin{tabular}{llll} 
Procedure & Male & Female & Porcentage \\
\hline Hemorroidectomy & 32 & 49 & 32 \\
Cutaneous apendix resection & 12 & 16 & 12 \\
Fistulotomy & 39 & 32 & 32 \\
Biopsy & 20 & 21 & 19 \\
Esfinterotomy & 13 & $137(54 \%)$ & 13 \\
Total & $116(45.84 \%)$ & $253(100 \%)$ \\
\hline Note: Data from the recollection instrument designed for this study, using the patient's chart (2017). \\
\hline
\end{tabular}

Table 2 - Pain tolerance according Visual Analogicals (VAS).

\begin{tabular}{llll} 
Pain tolerance & Female & Male & Porcentage \\
\hline Excellent & 21 & 16 & 6 \\
Good & 92 & 81 & 68 \\
Bad & 17 & 16 & 14 \\
Badly & 4 & 6 & 2 \\
Total & $134(52 \%)$ & $119(48 \%)$ & $253(100 \%)$ \\
\hline Note: Data from the recollection instrument designed for this study, using the patient's chart (2017). & \\
\hline
\end{tabular}

\section{Inclusion criteria}

Patients of all ages surgically intervened who presented a low-complexity anorectal disease: hemorrhoids, anal flap resection, previous anorectal disease without surgery, no contraindication for local anesthetic, patients who agreed on the procedure and signed an informed consent.

\section{Exclusion criteria}

Patients with contraindication for using local anesthetic, suspicion of malignant or complex disease, patients who disagree and didnt signed the consent.

The collecting data instrument for documenting and observing the patient, who undergo surgery, had 3 parts: first identification data from the patient, including affiliation number, age, sex, diagnose. In the second part the anesthetic used were documented, surgical risk, and the last part refers to pain evaluation, intensity through visual analogical scale (VAS). All results were expressed descriptively in percentages tables.

\section{Technique}

A mix between $2 \%$ lidocaine and $0.050 \%$ bupivacaine was used, in a 70-30 proportion. Perianal skin is infiltrated with $10 \mathrm{cc}$. A deeper shot is administrated at 3, 6, 9 and 12 oćlock. The infiltration starts at 6 oćlock with 10cc, followed by $5 \mathrm{cc}$ at 5 and 7 . The needle pulls back and 5cc are injected at 3 oćlock and 5cc more at 2 and 4 . Same procedure is repeated at 9 and finally at 12 oćlock. All infiltrations, except the one on the perineal skin, are performed directed by the left hand index finger inside the rectum. After been discharged, patients have postoperative care indications and naproxen with esomeprazole is given every $12 \mathrm{~h}$ for 3 days. ${ }^{7,8}$

\section{Results}

253 procedures were performed with 116 local analgesia, 116 were male (45.86\%) year 137 female (54\%), Milligan-Morgan hemorroidectomy with Ligasure and fistulotomy were the most frequently performed procedures 32\% each, followed by biopsy $16 \%$, left lateral esfinterotomy $13 \%$ and cutaneous appendix $12 \%$.

Pain tolerance was evaluated through a visual analogical scale for pain transoperatively, one day postop and 5thday postop. This scale considerate: Excellent tolerance with 0-1 point, good 2-3 points, regular 4-5, bad 6-7 very bad tolerance 8-10 points.

Females' patients presented better pain tolerance than males $92 \%$ vs. $81.68 \%$.

\section{Conflicts of interest}

The authors declare no conflicts of interest.

\section{REFERE N C E S}

1. Martin MC, Roche B. Outpatient proctological surgery. Ambul Surg. 1998;6:25-8.

2. Goligher JC. Cirugía del Ano, Recto y Colon. España: Editorial Salvat; 1975. p. 88-9.

3. Gabrielli F, Cioffi U, Chiarelli M, Guttadauro A, De Simona M. Hemorrhoidectomy with Posterior Perineal Block: experience with 400 cases. Dis Colon Rectum. 2000;43:809-12.

4. Hunt L, Luck AJ, Rudkin G, Hewett PJ. Day case hemorrhoidectomy. Br J Surg. 1999;86:255-8

5. Esser S, Khubchandani I, Rakhmanine M. Stapled hemorrhoidectomy with local anesthesia can be performed safely and cost-efficiently. Dis Colon Rectum. 2004;47: 1164-9. 
6. Sobrado CW, Habr-Gama A. Hook-needle puncture. A new technique of local anesthesia for anorectal surgery. Dis Colon Rectum. 1996;39:1330-1.

7. Asik I, Kocum AI, Goktug A, Turhan KS, Alkis N. Comparison of ropivacaine $0.2 \%$ and $0.25 \%$ with lidocaine $0.5 \%$ for intravenous regional anesthesia. J Clin Anesth. 2009;21:401-7.
8. Kanai A, Osawa S, Suzuki A, Ozawa A, Okamoto H, Hoka S. Regression of sensory and motor blockade, and analgesia during continuous epidural infusion of ropivacaine and fentanyl in comparison with other local anesthetics. Pain Med. 2007;8:546-53. 